\title{
BEDA PENGARUH ARKUS KAKI TERHADAP KESEIMBANGAN STATIS ANAK USIA 9-12 TAHUN DI SD NEGERI MOJOLEGI, TERAS, BOYOLALI
}

\author{
M. Syafi'i ${ }^{1}$, Sri Surini Pudjiastuti ${ }^{2}$, Philipus Prihantiko K. ${ }^{3}$ \\ 1,2,3 Jurusan Ortotik Prostetik, Politeknik Kesehatan Kemenkes Surakarta \\ Email:amfi86@gmail.com,srisurini_pudjiastuti@yahoo.co.id,prihantiko@gmail.com
}

\begin{abstract}
Determine Differences in The Normal Foot and Flat Foot Against Static Balance in Children Aged 9-12 Years in SD Negeri Mojolegi, Teras, Boyolali. The purpose of this study was to determine differences in the normal foot and flat foot against static balance in children aged 9-12 years. A number of 60 healthy subjects were divided into two groups. Each group were 30 people. Group I is the group with normal arches condition and the second group is a flat foot arch condition. Location of this study was Mojolegi elementary school, Teras, Boyolali and was used the measuring tool Wet Test and One Legged Stance Test. This study was a cross sectional nonexperimental design. Each group were tested the normality of the data by the KolmogorovSmirnov. Analytic test in Group I and II showed that the value of $\mathrm{p}>0.05$, distribution of data were normal. Both groups were tested by Independent $\mathrm{T}$ Test, then the result showed $\mathrm{p}<0.05$, there were significant differences between the normal arch and flatfoot arch condition in maintaining static equilibrium position.
\end{abstract}

Keywords: The balance, Arch of the foot

\begin{abstract}
Abstrak: Beda Pengaruh Arkus Kaki terhadap Keseimbangan Statis Anak Usia 9-12 Tahun di SD Negeri Mojolegi, Teras, Boyolali.. Tujuan penelitian ini adalah untuk mengetahui perbedaan normal foot dan flat foot terhadap keseimbangan statis pada anak usia 9-12 tahun. Sejumlah 60 subyek sehat, terbagi menjadi dua kelompok. Masing- masing kelompok 30 orang. Kelompok I adalah Kelompok dengan kondisi arkus normal dan kelompok II adalah kondisi arkus flat foot. Dilakukan di SD Negeri Mojolegi, Teras, Boyolali. Dengan menggunakan alat ukur Wet Test dan One Legged Stance Test. Penelitian ini merupakan non eksperimental cross sectional design. Masing-masing kelompok diuji normalitas data dengan Kolmogorov-Smirnov Test pada Kelompok I menujukkan nilai $p>0,05$ maka data berdistribusi normal dan Kelompok II menunjukkan nilai $\mathrm{p}>0,05$ maka data berdistribusi normal. Pada kedua kelompok diuji hipotesis dengan Independent $T$ Test dengan hasil $p<0,05$ maka terdapat perbedaan yang signifikan antara kondisi arkus normal dan kondisi arkus flatfoot dalam mempertahankan keseimbangan statis. Berdasarkan analisis statistik penelitian yang telah dilakukan dapat disimpulkan bahwa terdapat perbedaan yang signifikan antara kondisi arkus normal dan kondisi arkus flatfoot dalam mempertahankan posisi keseimbangan statis.
\end{abstract}

Kata kunci: Keseimbangan, Lengkungan kaki

Seiring berjalannya waktu dan perkembangan zaman yang makin maju banyak masalah juga ditemui, salah satunya masalah dalam bidang kesehatan. Gangguan kesehatan yang banyak dialami salah satunya adalah gangguan pada musculoskeletal. Gangguan musculoskeletal dapat menyerang siapa saja mulai dari saat lahir sampai dewasa. World Health Organization (WHO) memberikan peryataan bahwa terdapat ratusan juta orang terganggu kehidupan akibat gangguan musculoskeletal. Gangguan musculoskeletal yang banyak dijumpai adalah kaki datar atau yang biasa disebut flat foot. Menurut Evans sekitar 20$30 \%$ dari seluruh anak di dunia mengalami flat foot dan menurut Pande ketut, sekitar $18 \%$ atau 6 dari 33 anak memiliki kecenderungan flat foot hasil ini diperoleh dari hasil survey yang dilakukan di SDN Coblong 2 Bandung (Wardanie, 2013).

Prevalensi flat foot pada kelompok anak berusia 3 tahun adalah sebesar 54\% dan pada kelompok anak berusia 6 tahun sebesar $24 \%$. Sebagian besar anak akan menunjukkan perkembangan normal dari telapak kaki secara utuh pada usia 10 tahun (Rodriguez, 1999).

Pada usia anak besar keinginan untuk melakukan aktifitas fisik berkembang pesat, hal ini memberikan kemungkinan meningkatkan kualitas kemampuan fisik dan geraknya menjadi 
lebih besar dan bila mengalami keterlambatan pada kemampuan motorik, maka anak akan mengalami keterlambatan perkembangan dan pertumbuhan (Permana, 2013).

Apabila kaki datar diderita maka seseorang individu tidak saja sukar berjalan, tetapi juga mengalami masalah keseimbangan badan, kajian yang dilakukan di Taiwan didapatkan, 8700 individu dewasa berumur 30 tahun ke atas mengalami berbagai masalah akibat komplikasi pada kaki. Ini terjadi karena kelainan pada kaki merusak secara perlahan-lahan dan keluhan baru akan muncul ketika 5-10 tahun, tidak semua kondisi flat foot menyebabkan seseorang mengalami masalah gangguan keseimbangan karena secara fisiologis keseimbangan tubuh anak-anak ditentukan oleh fungsi neurologis sistem otak dan sistem vestibular (alat keseimbangan), pada kelompok siswa ini kedua fungsi tersebut berkembang normal. Disamping itu, anak-anak telah melakukan permainan yang memerlukan keseimbangan tubuh sejak masa taman kanak-kanak (Lendra, 2009).

Kemampuan anak untuk dapat melakukan gerakan tubuh secara terkoordinasi dibutuhkan untuk melatih kelenturan, keseimbangan, dan kelincahan. Gerak berfungsi sebagai pintu gerbang masuknya pengetahuan dan stimulasi yang diperlukan untuk membangkitkan serta mengembangkan potensi dalam diri anak. Anak yang diberikan banyak kesempatan untuk bergerak dan melatih fisiknya terutama motorik kasarnya, akan terbantu dalam percepatan kematangan sarafnya yang bermuara pada kesiapan belajar di tahap berikutnya secara optimal dan lebih baik. Hal ini mengingat kemampuan yang paling berkembang pesat pada usia dini adalah kemampuan motorik atau fisiknya. Keseimbangan tubuh merupakan fungsi yang amat vital bagi manusia seperti halnya panca-indera. Pada anak, keseimbangan tubuh yang dimiliki, membantunya untuk dapat melakukan kegiatan sehari-hari terutama yang berhubungan dengan sistem visual atau penglihatan, seperti melihat benda, memperkirakan ruang, serta menempatkan diri secara tepat pada sebuah kondisi (Wiwik Chitra Pratiwi \& Munawar, 2014).

Pengetahuan tentang pertumbuhan lengkungan kaki berguna untuk pencegahan deformitas selanjutnya, diagnosis dini, manajemen, dan prediksi pertumbuhan karena aktivitas anak-anak lebih banyak menggunakan kaki, kaki merupakan bagian yang berfungsi untuk menopang berat badan. Jika penopang itu tak kokoh, bukan tidak mungkin tubuh sering jatuh dan akhirnya merusak bangunan tubuh secara keseluruhan (Ariani, Wibawa, \& Muliarta, 2014).

Tujuan penelitian ini, untuk mengetahui: perbedaan normal foot dan flat foot terhadap keseimbangan statis pada anak usia 9-12 tahun. Manfaat penelitian yang diharapkan: 1) manfaat bagi penulis, sebagai penambah pengalaman, wawasan dan pemahaman mengenai perbedaan keseimbangan statis antara flat foot dan normal foot, masukan untuk mengoptimalkan dalam pemberian ortosis untuk meningkatkan keseimbangan pada anak, 2) manfaat untuk institusi pendidikan, menambah pengetahuan tentang perbedaan keseimbangan statis flat foot dan normal foot pada anak usia 9-12 tahun, 3) untuk masyarakat umum (orang tua), memberitahukan informasi tentang perbedaan keseimbangan statis flat foot dan normal foot sehingga anak yang mengalami flat foot mendapat penanganan dini yang dapat mencegah deformitas yang berlanjut.

\section{METODE PENELITIAN}

Desain penelitian ini adalah analitik dengan pendekatan cross-sectional. Populasi meliputi siswa kelas 4-6 baik laki-laki maupun perempuan di SD Negeri Mojolegi, Teras, Boyolali yang berjumlah 144 siswa, sampel 60 siswa (30 sampel dengan kondisi arkus normal dan 30 sampel dengan kondisi arkus flat foot). Teknik pengambilan sampel disesuaikan dengan kriteria tertentu, yaitu kriteria inklusi: 1) Siswa SD N Mojolegi, Teras, Boyolali, 2) Berusia 9-12 tahun, 3) Memberikan persetujuan menjadi sampel penelitian. Sedangkan kriteria eksklusi: 1) Subyek dalam keadaan sakit, 2) Memiliki deformitas selain pes planus/flat foot, pes cavus, scoliosis, metatar-salgia.

Metode pengambilan sampel Purposive Sampling. Teknik ini tidak memberikan kesempatan yang sama bagi setiap anggota populasi untuk dipilih sebagai sampel.

Purposive Sampling yaitu metode penetapan responden menjadi sampel berdasarkan kriteria-kirteria tertentu (Siregar, 2013). Semua subyek yang masuk dalam kriterian inklusi, diukur keseimbangannya dengan one legged stance balance. Alat-alat yang diperlukan dalam pelaksanaan test antara lain: stopwatch.

Prosedur tes dijelaskan seperti berikut, posisi awal subyek berdiri dengan dua kaki tanpa menggunakan alas kaki dan kedua tangan diletakkan di pinggang. Pada saat peneliti memberi aba-aba "mulai" satu kaki diangkat. Waktu dihitung sejak aba-aba "mulai" sampai 
anak kehilangan keseimbangan seperti, menggeser telapak kaki, tangan berubah posisi, dan lain-lain.

\section{HASIL}

Tabel 1. Distribusi Frekuensi Jenis Kelamin

\begin{tabular}{lrr}
\hline Jenis Kelamin & \multicolumn{1}{l}{ n } & \% \\
\hline Laki - laki & 28 & 47 \\
Perempuan & 32 & 53 \\
\hline Jumlah & 60 & 100 \\
\hline
\end{tabular}

Berdasarkan tabel 1 karakteristik subyek penelitian berdasarkan jenis kelamin sebagai berikut: (1) laki-laki sebanyak 28 subjek (47\%) dan perempuan sebanyak 32 subyek (53\%).

Tabel 2. Distribusi Frekuensi Kondisi Arkus Kaki

\begin{tabular}{lrr}
\hline \multicolumn{1}{c}{ Kondisi } & n & \% \\
\hline Normal Foot & 30 & 50 \\
Flatfoot & 30 & 50 \\
\hline Jumlah & 60 & 100 \\
\hline
\end{tabular}

Dari tabel 2 karakteristik subyek penelitian berdasarkan kondisi arkus kaki sebagai berikut: (1) kondisi arkus kaki normal sebanyak 30 subjek $(50 \%)$ dan kondisi arkus flat foot sebanyak 30 subyek (50\%).

Tabel 3. Distribusi Frekuensi Usia, Berat Badan dan Tinggi Badan

\begin{tabular}{cccccc}
\hline $\begin{array}{c}\text { Karak- } \\
\text { teristik }\end{array}$ & n & Min & Mak & Rerata & SD \\
\hline Usia & 60 & 9 & 12 & 10,75 & 1,215 \\
Berat & 60 & 25 & 58 & 38,56 & 7,164 \\
Tinggi & 60 & 130 & 156 & 142,86 & 6,088 \\
\hline
\end{tabular}

Dari tabel 3 karakteristik subyek penelitian berdasarkan usia, berat badan, dan tinggi badan sebagai berikut: (1) usia minimal 9 tahun, usia maksimal 12 tahun, rerata usia 10,75 tahun dan standar deviasi 1,125 . (2) berat minimal $25 \mathrm{~kg}$, berat maksimal $58 \mathrm{~kg}$, rerata berat badam 38,56 kg dan standar deviasi 7,164. (3) tinggi minimal $130 \mathrm{~cm}$, tinggi maksimal 156 $\mathrm{cm}$, rerata tinggi badan $142,86 \mathrm{~cm}$ dan standar deviasi 6,088 .

Tabel 4. Keadaan Subyek Penelitian \begin{tabular}{rcr|rrrl}
\multicolumn{8}{c}{ Kondisi } & \multicolumn{4}{c}{ Arkus Kaki Normal } \\
\hline & n & Min & Mak & Rerata & SD \\
\hline Normal & 30 & 5 & 164 & 78,2 & 45,20 \\
\hline
\end{tabular}
Berdasarkan tabel 4 didapatkan hasil bahwa keadaan subyek penelitian kondisi arkus kaki normal mempunyai rentang minimal sebesar 5 detik dan maksimal 164 detik, rerata 78,2 detik dan standar deviasi sebesar 45,20.

Tabel 5. Keadaan Subyek Penelitian Kondisi Arkus Kaki Flatfoot

\begin{tabular}{lrrrrr}
\hline $\begin{array}{l}\text { Kondisi } \\
\text { arkus kaki }\end{array}$ & n & Min & Mak & Rerata & Sd \\
\hline Flat foot & 30 & 5 & 96 & 38,53 & 26,90 \\
\hline
\end{tabular}

Berdasarkan tabel 5 didapatkan hasil bahwa keadaan subyek penelitian kondisi arkus kaki flat foot mempunyai rentang minimal sebesar 5 detik dan maksimal 96 detik, rerata 38,53 detik dan standar deviasi sebesar 26,90.

Tabel 6. Uji Normalitas Data KolmogorovSmirnov

\begin{tabular}{lcl}
\hline \multicolumn{1}{c}{ Kelompok } & Sig & Intepretasi \\
\hline Normal foot & 0,200 & Normal \\
Flatfoot & 0,013 & Normal \\
\hline
\end{tabular}

Berdasarkan tabel 6 mengenai uji normalitas didapatkan hasil uji normalitas untuk kondisi arkus kaki normal $p=0,200$ dimana $p>0,05$ maka dapat disimpulkan data berdistribusi normal. Sedangkan uji normalitas untuk kondisi arkus kaki flat foot dihasilkan $p=0,013$ dimana $p>0,05$ maka dapat disimpulkan data berditribusi normal. Hasil keduanya selanjutnya dilakukan uji hipotesis dengan independet t test.

Tabel 7. Uji Hipotesis

\begin{tabular}{lll}
\hline Kelompok & Sig & Intepretasi \\
\hline $\begin{array}{l}\text { Normal foot } \\
\text { dan } \text { flatfoot }\end{array}$ & 0,000 & $\begin{array}{l}\text { Ada perbedaan } \\
\text { yang signifikan }\end{array}$ \\
\hline
\end{tabular}

Berdasarkan tabel 7 , didapatkan hasil $p=0,000$ dimana $p<0,05$ maka dapat diambil kesimpulan yaitu terdapat perbedaan yang signifikan antara keadaan arkus kaki normal dan arkus kaki flat foot terhadap keseimbangan statis.

\section{PEMBAHASAN}

Penelitian yang diadakan pada bulan Januari tahun 2016 di SD Negeri, Mojolegi, Teras, Boyolali dengan subyek siswa dengan rentang usia 9-12 tahun didapatkan jumlah populasi 144 anak dengan 60 siswa laki-laki atau sebesar $41 \%$ dan 84 siswa perempuan atau sebesar 59\%. Berdasarkan penelitian didapatkan 33 siswa dengan kondisi arkus flatfoot dan 111 siswa dengan kondisi arkus normal dari 144 
siswa yang diperiksa kondisi arkus nya, maka prevalensi yang didapat $23 \%$ kondisi arkus flat foot dan $77 \%$ kondisi dengan arkus normal.

Kondisi dengan arkus normal mempunyai rentang waktu lebih lama dalam mempertahankan keseimbangan dengan one legged stance test daripada kondisi arkus flatfoot yang mana berarti memiliki keseimbangan statis yang lebih baik seperti yang diungkapkan oleh Dhanani yang berpendapat bahwa asumsi pokok dalam keseimbangan statis adalah ketika seorang individu dapat mempertahankan lebih lama maka keseimbangan statisnya lebih baik.

Berdasarkan uji hipotesis didapatkan hasil bahwa ada perbedaan yang signifikan kondisi arkus normal degan kondisi arkus flatfoot dalam mempertahankan keseimbangan statis.

Hasil penelitian ini serupa dengan beberapa literatur yang dikemukakan Hsing, 2007; Anse,1999; Pryce, 2006; Meidy, 2007, Naylor, 1999; Abdurrahman, 2003; Ferry, 2006 bahwa anak dengan kondisi arkus flatfoot mempunyai tingkat keseimbangan yang buruk. (Lendra, 2009)

Ketika seseorang mengalami flatfoot hal yang menjadi masalah adalah apabila kedudukan tapak kaki bergeser atau hilangnya kesejajarannya karena ia akan mempengaruhi struktur tubuh (Lendra, 2009) ketika kesejajaran tubuh berubah maka center of gravity dari tubuh akan berubah. Fungsi dari Center of gravity adalah untuk mendistribusikan massa benda secara merata, pada manusia beban tubuh selalu ditopang oleh titik ini, maka tubuh dalam keadaan seimbang. Tetapi jika terjadi perubahan postur tubuh maka titik pusat gravitasi pun berubah, maka akan menyebabkan gangguan keseimbangan (Unstable) (Nadiaty, 2015). Menurut Hsing jika flatfoot dialami oleh seseorang maka seseorang tersebut mengalami sukar berjalan tetapi juga dapat mengalami gangguan keseimbangan.

Penelitian mengenai arkus kaki yang dihubungkan dengan keseimbangan statis maupun dinamis banyak dilakukan seperti Penggunaan Medial Arch Support dan keseimbangan dinamis pada kondisi flat foot. (Sri Surini Pudjiastuti et all, 2012) dimana Hasilnya berupa peningkatan keseimbangan dinamis subyek yang diberi perlakuan dengan sedangkan yang tidak diberi perlakuan tidak ada perubahan yang berarti. Maka dapat disimpulkan bahwa kondisi arkus normal dan kondisi arkus flatfoot terdapat perbedaan yang berpengaruh terhadap keseimbangan sesuai dengan penelitian yang dilakukan oleh penulis.

\section{SIMPULAN}

Berdasarkan hasil penelitian disimpulkan bahwa, dari 60 subyek penelitian dengan 30 subyek dengan kondisi arkus kaki normal dan 30 anak untuk kondisi arkus kaki flatfoot. Subjek laki-laki 28 siswa dan perempuan 32 siswa. Prevalensi siswa dengan kondisi arkus normal $77 \%$ dan kondisi arkus flatfoot $23 \%$.

Selanjutnya untuk kondisi aekus normal dengan rerata 78,2 detik dan kondisi arkus flatfoot dengan rerata 38,53 , dan terdapat perbedaan yang signifikan antara kondisi arkus normal dan arkus flat foot dalam mempertahankan keseimbangan statis anak usia 9-12 tahun.

\section{DAFTAR PUSTAKA}

Ariani, L., Wibawa, A., \& Muliarta, I. 2014. Aplikasi Heel Raises Exercise dapat meningkatkan lengkungan kaki dan keseimbangan statis pada anak-anak flat foot usia 4-5 tahun di TK Aisyiyah Bustanul Athfal 3 Denpasar.

Lendra, M. D. 2009. Beda Pengaruh Kondisi Kaki datar dan kaki dengan arkus terhadap keseimbangan statis pada anak usia 8-12 tahun di kelurahan Karangasem, Surakarta. Jurnal Fisioterapi. Vol. 9 No. 2, 49-58.

Permana, D. F. 2013. Perkembangan Keseimbangan pada Anak Usia 7 s/d 12 Tahun Ditinjau dari Jenis Kelamin. Jurnal Media Ilmu Keolahragaan Indonesia, 25-29.

Rodriguez, A. G. 1999. Flexible Flat Feet in Children: A Real Problem. Journal Pediatrics. Vol. 103, No.6.

Siregar, S. 2013. Statistik Parametik Untuk Penelitian Kuantitatif Dilengkapi Dengan Perhitungan Manual dan Aplikasi SPSS Versi 17. Jakarta: Bumi Aksara.

Wardanie, S. 2013. Prevalensi Kelainan bentuk kaki (Flat Foot) pada anak usia 6-12 tahun di kota Surakarta.

Wiwik Chitra Pratiwi \& Munawar, M. 2014. Peningkatan Keseimbangan tubuh melalui berjalan diatas versa disc pada anak kelompok B PAUD taman Belia Candi Semarang. Jurnal Penelitian PAUDIA, 40-62. 